\title{
Industrial Engineering Students' Perceptions of the Logistics and Supply Chain Industry
}

\section{Dr. Christina R. Scherrer, Kennesaw State University}

Christina Scherrer is an associate professor of Systems and Industrial Engineering in the Southern Polytechnic College of Engineering \& Engineering Technology at Kennesaw State University. Her research interests are in the application of operations research and economic decision analysis to the public sector and in assessing education innovation. She teaches primarily statistics and logistics courses, at both the undergraduate and graduate level.

\section{Michael Maloni, Kennesaw State University \\ Dr. Elizabeth M. Boyd, Kennesaw State University}

Dr. Elizabeth M. Boyd received her BS in Psychology from Central Michigan University and her MA and $\mathrm{PhD}$ from Michigan State University in Organizational Psychology. She is an Assistant Professor of Management and Entrepreneurship at Kennesaw State University and serves as the Research Director for the Women's Leadership Center at KSU.

Dr. Boyd has taught graduate and undergraduate courses in research methods, psychometrics, organizational psychology, management, and gender. Her research focuses on gender issues in organizations and the challenges people face when attempting to balance multiple life roles and goals. Her recent work has explored the effectiveness of employee resource groups for women and how work-family conflict may impact the leaky-pipeline phenomenon.

\section{Dr. Stacy M. Campbell, Kennesaw State University}

Stacy M. Campbell is the Director of the Scholars Program and an Associate Professor of Management in the Michael J. Coles College of Business at Kennesaw University. Dr. Campbell teaches both undergraduate and graduate classes on Managing Organizations, Leading \& Teaming and Consulting. Her research interests include leadership and narcissism, generational differences in work values, and improving student success in online learning. Dr. Campbell's work has appeared in the Journal of Management, Leadership Quarterly, Journal of Managerial Psychology, Human Resource Management Journal, and the Journal of Social and Personality Psychology. Her work has also been featured in Atlanta-Journal Constitution, Chronicle of Higher Education, BusinessWeek, US News \& World Report, and the New York Post. Prior to her doctoral studies, Dr. Campbell worked as a management consultant for KPMG consulting and more recently, the Atlanta-based consulting firm, The North Highland Company, in their change management practice. She received a PhD from the University of Georgia, a M.A. in psychology from UNC-Chapel Hill, and a BBA in economics/business and psychology from Lafayette College, Easton, PA. 


\title{
Industrial Engineering Students' Perceptions of the Logistics and Supply Chain Industry
}

\begin{abstract}
A shortage of logistics and supply chain talent is a significant and growing problem in the industry. However, little research has been done to study why industrial engineering (IE) students are not entering the field in sufficient numbers. This paper addresses several questions to begin to close that knowledge gap. First, what are undergraduate IE students' awareness of and interest in the logistics and supply chain industry? Second, what are IE students' desired job attributes? Finally, are there differences between IE students' responses to these questions and those of business students that would suggest a need to market to IE students differently? Data is collected from more than 1,500 undergraduate industrial engineering and business students throughout the state of Georgia. Analysis is presented for various demographics, including gender, age, and ethnicity.
\end{abstract}

\section{Introduction}

Logistics is an important and growing field. In 2014, total US logistics costs were $\$ 1.45$ trillion, which represents $8.3 \%$ of GDP [1]. However, there is a need for more college students to choose careers in this field. Traditionally fed from business and industrial engineering programs, logistics faces a current shortage of students entering the field. The Georgia Center of Innovation for Logistics reports that there was a gap of more than 270,000 logistics related job openings in the US in 2012 [2]. Many other sources mention the same shortage of logistics talent entering the workforce (see, for example, [3,4,5]). Ozment and Keller studied AACSB accredited business schools and found that $90 \%$ of their students likely graduate with little or no understanding of logistics [6]. While part of the problem may be that students don't know about the field [7], others believe both that it is difficult to get students interested in logistics even when they are informed [8] and that the field has an image problem [9].

Industrial engineering faculty have an opportunity to help pair students' interests and job expectations with the logistics industry. The authors believe that many students would be interested in a career in logistics if they were better informed about the options available to them. For these reasons, the authors partnered with the Georgia Department of Economic Development to study the career expectations of undergraduate students in industrial engineering and business programs as well as their thoughts about logistics careers. It is the authors' hope that results from this study can be used to determine gaps in our students' understanding of logistics careers and to motivate their interest in the field of logistics. Knowing more about what students are looking for in a job can also help faculty to better mentor them about realistic workplace expectations.

\section{Methods}


To obtain information about students' awareness of and interest in the logistics and supply chain industry and about their future job expectations, students from seven public universities in Georgia were surveyed. The survey was administered to approximately 7,000 undergraduate industrial engineering and business students in Qualtrics. Students were sent several e-mail reminders of the survey over the time period that the survey was open from faculty/administrators at their home college and, to further incent participation, students who completed the survey were entered into a drawing for a free iPad. This resulted in almost one fourth of the students completing the survey. The 1,618 usable undergraduate student responses were split into 253 from industrial engineering students and 1,365 from business students. Table 1 includes demographic information for both subsamples.

Table 1: Self-reported demographics for the engineering and business students

\begin{tabular}{|l|r|r|}
\hline Percent male & $\begin{array}{r}\text { Engineering } \\
\text { Students }\end{array}$ & $\begin{array}{r}\text { Business } \\
\text { Students }\end{array}$ \\
\hline Average GPA & $54.2 \%$ & $43.1 \%$ \\
\hline Average AGE & 3.3 & 3.2 \\
\hline Ethnicity & 22.8 & 26.3 \\
\hline Asian & & \\
\hline African American & $23.7 \%$ & $6.6 \%$ \\
\hline White & $7.9 \%$ & $24.6 \%$ \\
\hline Hispanic & $60.5 \%$ & $63.8 \%$ \\
\hline Other & $10.3 \%$ & $7.0 \%$ \\
\hline Student Status & $2.4 \%$ & $3.9 \%$ \\
\hline Freshman & & \\
\hline Sophomore & $3.5 \%$ & $9.6 \%$ \\
\hline Junior & $12.2 \%$ & $20.2 \%$ \\
\hline Senior & $23.2 \%$ & $26.6 \%$ \\
\hline Work Experience & $61.0 \%$ & $43.7 \%$ \\
\hline Previous part-time job & $60.1 \%$ & $67.1 \%$ \\
\hline Previous internship & $67.2 \%$ & $27.9 \%$ \\
\hline Previous full-time job & $21.3 \%$ & $45.3 \%$ \\
\hline No work experience & $4.7 \%$ & $5.7 \%$ \\
\hline
\end{tabular}

To design the survey, the authors studied the literature on job characteristics and generated a comprehensive list of job expectations. Using the collective knowledge of the authors with respect to psychology and organizational behavior, the list was reduced to 44 specific characteristics. The authors then ran a pilot study with 409 undergraduate students to further reduce the characteristics studied in the final survey to the 22 most significant. The final survey asked students to evaluate each of those 22 characteristics using the prompt "Thinking ahead to after college graduation, how important is each item below for your ideal job?" Students were requested to choose their answer on the Likert scale from $1=$ not important to $5=$ essential. 
Using exploratory factor analysis, the 22 characteristics were categorized into seven different factors, defined in Table 2. Five of these factors (intrinsic, extrinsic, social, altruistic, and leisure) directly align with factors found in the work by Twenge et al [10] with a large longitudinal data set from the Monitoring the Future project. The two additional factors (longterm and supervision) were from other literature on work expectations found in these age groups $[11,12,13]$.

Table 2: Job Expectation Factors

\begin{tabular}{|c|l|}
\hline Factors & \multicolumn{1}{|c|}{ Description } \\
\hline Intrinsic & $\begin{array}{l}\text { Does the job provide a sense of personal meaning (be creative, learn, see } \\
\text { results, maintain current skills)? }\end{array}$ \\
\hline Extrinsic & $\begin{array}{l}\text { Does the job provide financial rewards, promotion, respect, and prestige? } \\
\text { Does the job provide contact and common interests with others, opportunity } \\
\text { to make friends? }\end{array}$ \\
\hline Altruistic & Does the job provide the opportunity to help others, be worthwhile to society? \\
\hline Leisure & Does the job provide balance (slow pace, vacation, time for other things)? \\
\hline Long Term & $\begin{array}{l}\text { Does the job provide stability and long-term benefits (health care, } \\
\text { retirement)? }\end{array}$ \\
\hline Supervision & $\begin{array}{l}\text { Does the job provide detailed instruction, frequent feedback, personal } \\
\text { support? }\end{array}$ \\
\hline
\end{tabular}

The survey then asked students questions to gauge their familiarity with and interest in logistics. The first was, "Prior to this survey, what was your familiarity with the field of logistics"? They were then provided a brief definition of logistics and asked to rate their agreement with the following three statements on a Likert scale of $1=$ strongly disagree to 5=strongly agree:

1. A career in the field of logistics seems like a good idea to me.

2. It is likely that my career will be in the field of logistics.

3. I am interested in a career in the field of logistics.

Results were then analyzed statistically for the various demographics and are presented below.

\section{Results}

\section{Interest in Logistics}

Figure 1 displays the answers to the questions about students' knowledge of and interest in logistics. The difference between the means of the answers from the engineers and the business students were statistically significant for each question, at an alpha $=0.001$ level. Overall the industrial engineers were more familiar with logistics, were more likely to agree that a logistics career was a good idea (mean $=3.96$ vs. 3.56 ), that they were 
interested in a career in logistics (3.72 vs. 3.19), and that a logistics career was likely for them (3.27 vs. 2.67).

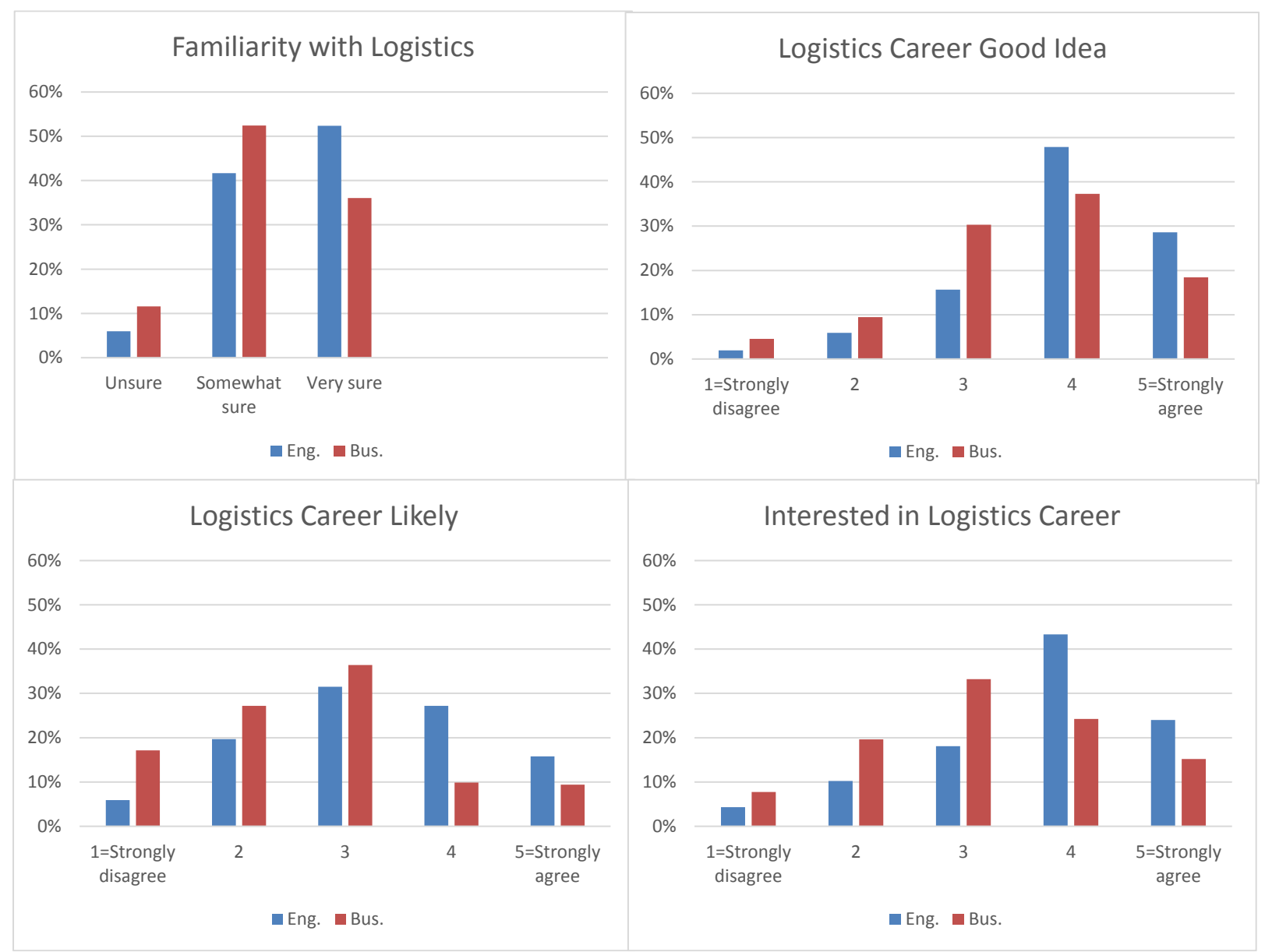

Figure 1: Knowledge of and interest in logistics for engineering majors versus business majors.

While few industrial engineers (6\%) said that they were unsure about the field of logistics, only about half (52\%) said that they were very familiar with it. If we look at the subset of engineering students that are upperclassmen, the numbers were very similar (6\% unsure and 54\% very sure). This clearly illustrates an opportunity for further education about this significant field within industrial engineering.

Seventy-six percent of the engineering students agreed or strongly agreed with the statement that a career in logistics seems like a good idea, and $67 \%$ agreed that they were interested in such a career, but only $43 \%$ said that a logistics career was likely. Perhaps this represents a lack of knowledge of the career opportunities that exist in logistics. Reducing the gap between students who think that a career in logistics is a good idea and 
those that end up eventually choosing such a career is a significant opportunity for workforce growth.

It is notable that among the engineering students who reported that they were very familiar with the field of logistics $(n=132)$, the percentages of students interested in logistics careers were significantly higher. Eighty percent of those engineering students agreed or strongly agreed with the statement that a career in logistics seems like a good idea, $71 \%$ were interested in such a career and $49 \%$ said that a logistics career was likely. That is a statistically significant difference ( $p$-value $=0.06$ ) in those saying a logistics career is likely between those engineers that reported they were very familiar with logistics and those that reported that they were only somewhat familiar or that they were unsure about logistics. This implies that simply educating students about logistics could potentially be a viable area of growth.

Industrial engineering is one of the engineering majors that tends to have a larger percentage of women undergraduates, as represented by $46 \%$ of the industrial engineering survey respondents being female. However, within the jobs that IEs fill, logistics still tends to be a male-dominated field. Drilling further down to look at just the female responses $(n=115)$ in the engineering subsample, seventy-seven percent of the women agreed or strongly agreed with the statement that a career in logistics seems like a good idea, $70 \%$ were interested in such a career, and $51 \%$ said that a logistics career was likely. Compared to the male engineers, a higher percentage said that a logistics career was likely ( $p$-value $=0.025$ ), but the other two questions were not statistically significantly different between gender. It is encouraging that female IEs appear to be interested in logistics careers in significant numbers. Further encouraging is that interest could improve some of the gender imbalances in the field as well as growing the overall number of students choosing a career in logistics.

\section{Desired Job Attributes}

Table 3 provides the means of the student responses to the question, "Thinking ahead to after college graduation, how important is each for your ideal job?" Results are sorted from most to least important for the whole sample. Questions where the difference between the IE students' response and the business students' response was statistically significant are noted with asterisks.

In the general sample, students indicated that extrinsic (specifically: chances for promotion, pay), intrinsic (see results, learn), long term (secure future, retirement, benefits), and supervision (support personal commitments, frequent feedback) factors were most important to their future careers. Leisure (vacation, slow pace) and social (friends, contacts, common interest) factors ranked low relative to the other factors.

There were some significant differences between business and engineering students. The top four factors were the same, but in different order with the intrinsic (see results of what you do, learn new things) the top two for the engineers. Opportunities for promotion and good healthcare benefits also ranked highly. In general, all long term 
factors (secure future, retirement, benefits) and some extrinsic (promotion, money) characteristics were less important to engineers than business majors. Two social characteristics (friends, contact) were higher in importance for engineers. These differences show that marketing messages should be tailored differently to recruit engineers versus business students.

Table 3: Student Importance of Job Factors

\begin{tabular}{|l|l|c|c|l|}
\hline \multirow{2}{*}{ Factor } & \multirow{2}{*}{ Survey Question } & \multicolumn{3}{c|}{ Average Student Responses } \\
\cline { 3 - 5 } & & All & Business & Engineer \\
\hline Extrinsic & Chances for promotion are good & 4.33 & 4.35 & $4.20^{*}$ \\
\hline Intrinsic & See results of what you do & 4.31 & 4.31 & 4.31 \\
\hline Intrinsic & Learn new things, skills & 4.25 & 4.23 & 4.32 \\
\hline Long Term & Good health care, benefits & 4.24 & 4.27 & $4.03^{* *}$ \\
\hline Long Term & Predictable, secure future & 4.17 & 4.21 & $3.87^{* *}$ \\
\hline Long Term & Good retirement plan (e.g., 401K) & 4.09 & 4.13 & $3.85^{* *}$ \\
\hline Extrinsic & Chance to earn good deal of money & 4.07 & 4.10 & $3.87^{* *}$ \\
\hline Supervision & Supervisor supports personal commitments & 3.97 & 3.98 & 3.91 \\
\hline Intrinsic & Skills will not go out of date & 3.96 & 4.00 & $3.68^{* *}$ \\
\hline Intrinsic & Chance to be creative & 3.68 & 3.67 & 3.67 \\
\hline Supervision & Receive frequent feedback & 3.67 & 3.66 & 3.69 \\
\hline Altruistic & Opportunity to be helpful to others & 3.65 & 3.65 & 3.59 \\
\hline Altruistic & Worthwhile to society & 3.62 & 3.61 & 3.61 \\
\hline Leisure & Leaves time for other things in life & 3.52 & 3.53 & 3.46 \\
\hline Extrinsic & People look up to, respect & 3.49 & 3.49 & 3.41 \\
\hline Supervision & Receive detailed instructions & 3.48 & 3.52 & $3.21^{* *}$ \\
\hline Leisure & Have more than 2 weeks' vacation & 3.28 & 3.29 & 3.23 \\
\hline Extrinsic & High status, prestige & 3.24 & 3.25 & 3.18 \\
\hline Social & Chance to make friends & 3.12 & 3.07 & $3.43^{* *}$ \\
\hline Social & Contact with a lot of people & 3.10 & 3.07 & $3.36^{* *}$ \\
\hline Social & Have common interests with co-workers & 3.09 & 3.08 & 3.17 \\
\hline Leisure & Easy pace, lets you work slowly & 2.24 & 2.25 & 2.17 \\
\hline Scale: 1 - & important to 5 - essential) & &
\end{tabular}

(Scale: 1 - not important to 5 - essential)

${ }^{* *}$ significant difference between business and engineering at $\alpha=0.001, *$ at $\alpha=0.01$

Looking within the engineering group at just the students who agreed or strongly agreed with the statement that that they were interested in a logistics career $(n=171)$, there were no notable differences with the whole engineering group, implying that IEs who are interested in a career in logistics are not different from IEs as a whole. 
Table 4 summarizes the average student responses by gender and ethnicity (selfreported). Most significantly, female engineering students rated both altruistic categories higher than men. This supports previous research that women are drawn to fields that have the potential to make a difference [14]. This suggests that stressing ways that logistics helps society would be good in explaining the field to women. Women also rated two of the three long term factors (retirement plan and benefits) as slightly more important than their male peers. The sample sizes were unfortunately too small for the various ethnicities to produce statistically significant differences between the subsamples, but there were some differences that warrant further study.

Table 4: Student Importance of Job Factors, by Demographic

\begin{tabular}{|c|c|c|c|c|c|c|c|}
\hline \multirow[b]{2}{*}{ Factor } & \multirow[b]{2}{*}{ Survey Question } & \multicolumn{6}{|c|}{ Average Student Responses } \\
\hline & & $\begin{array}{l}\text { Men } \\
(n=137)\end{array}$ & $\begin{array}{l}\text { Women } \\
(n=115)\end{array}$ & $\begin{array}{l}\text { African- } \\
\text { Amer. } \\
(n=20)\end{array}$ & $\begin{array}{l}\text { Asian } \\
(\mathrm{n}=54)\end{array}$ & $\begin{array}{l}\text { Hispanic } \\
(\mathrm{n}=20)\end{array}$ & $\begin{array}{l}\text { White } \\
(n=140)\end{array}$ \\
\hline Intrinsic & Learn new things, skills & 4.36 & 4.28 & 4.20 & 4.57 & 4.55 & 4.22 \\
\hline Intrinsic & Skills will not go out of date & 3.74 & 3.63 & 4.05 & 3.91 & 4.00 & 3.49 \\
\hline Intrinsic & See results of what you do & 4.22 & 4.41 & 4.25 & 4.28 & 4.70 & 4.26 \\
\hline Intrinsic & Chance to be creative & 3.74 & 3.61 & 3.80 & 3.69 & 4.20 & 3.59 \\
\hline Extrinsic & Chance to earn good deal of money & 3.96 & 3.76 & 4.20 & 3.91 & 4.15 & 3.74 \\
\hline Extrinsic & Chances for promotion are good & 4.26 & 4.14 & 4.45 & 4.04 & 4.50 & 4.16 \\
\hline Extrinsic & High status, prestige & 3.20 & 3.15 & 3.40 & 3.41 & 3.80 & 2.94 \\
\hline Extrinsic & People look up to, respect & 3.37 & 3.44 & 3.45 & 3.43 & 4.05 & 3.26 \\
\hline Supervision & Receive frequent feedback & 3.69 & 3.70 & 3.90 & 3.78 & 4.15 & 3.55 \\
\hline Supervision & Receive detailed instructions & 3.14 & 3.30 & 3.35 & 3.33 & 3.60 & 3.06 \\
\hline Supervision & Supervisor supports personal commitments & 3.85 & 3.97 & 3.55 & 3.93 & 4.00 & 3.89 \\
\hline Altruistic & Opportunity to be helpful to others & 3.39 & $3.83^{\star \star}$ & 3.45 & 3.67 & 3.70 & 3.53 \\
\hline Altruistic & Worthwhile to society & 3.40 & $3.85^{\star \star}$ & 3.50 & 3.70 & 3.70 & 3.55 \\
\hline Leisure & Have more than 2 weeks' vacation & 3.15 & 3.33 & 3.15 & 3.61 & 3.45 & 3.12 \\
\hline Leisure & Leaves time for other things in life & 3.35 & 3.57 & 3.10 & 3.61 & 3.55 & 3.45 \\
\hline Leisure & Easy pace, lets you work slowly & 2.09 & 2.27 & 2.10 & 2.57 & 2.25 & 2.01 \\
\hline Long Term & Good retirement plan (e.g., 401K) & 3.72 & $4.02^{*}$ & 3.85 & 3.78 & 3.80 & 3.88 \\
\hline Long Term & Good health care, benefits & 3.91 & $4.17^{*}$ & 4.10 & 3.98 & 4.10 & 4.03 \\
\hline Long Term & Predictable, secure future & 3.77 & 3.99 & 4.21 & 4.06 & 4.05 & 3.74 \\
\hline Social & Contact with a lot of people & 3.28 & 3.46 & 3.00 & 3.48 & 3.60 & 3.34 \\
\hline Social & Chance to make friends & 3.34 & 3.56 & 2.85 & 3.69 & 3.55 & 3.40 \\
\hline Social & Have common interests with co-workers & 3.09 & 3.27 & 2.79 & 3.35 & 3.40 & 3.11 \\
\hline
\end{tabular}

(Scale: 1 - not important to 5 - essential)

${ }^{* *}$ significant difference between men and women at $\alpha=0.001,{ }^{*}$ at $\alpha=0.05$

\section{Conclusions and Future Work}

Results from this survey yield some interesting insights and opportunities to grow the IE talent pool pursuing careers in logistics. With only a small majority of IEs reporting that they are 
well-informed about logistics, there is clearly opportunity for further education. Educating industrial engineering faculty about logistics so they can promote it in their classes and including information about logistics in the introductory engineering course are two possibilities. Providing logistics guest speakers or tour opportunities (such as distribution centers, airports or sea ports) or partnering with logistics companies on class projects can be other exciting options for students.

Survey results imply that students who are better informed about logistics may be more likely to plan to enter a career in logistics. There is a significant difference between the percentage of students who believed that a career in logistics is a good idea and those who said they are likely to pursue a career in logistics themselves. The gap was smaller for students who reported that they were very familiar with logistics. Determining what causes this gap and how to make it smaller would be a good direction for future study. In addition, female IEs were slightly more interested in a career in logistics than their male peers, which represents an opportunity to reduce gender imbalance in the field.

Industrial engineering students reported that the most important career aspects to them are a job that lets them see results of what they do and one that allows them to learn new things/skills. A job with opportunities for promotion and good healthcare benefits also ranked highly. That can be a starting point for marketing efforts toward IE undergraduates. It is notable that business students had slightly different priorities than IEs, information which should be helpful to logistics companies hiring IEs. Also, women more highly rated jobs that will let them be helpful to others or worthwhile to society, factors which companies might want to consider when recruiting women. For example, industry may also wish to enhance their websites to highlight the more impactful factors or develop a section of their website specifically targeted to engineers and women.

This work has several limitations. It is not possible to determine causality, so there is no way to prove whether interest in a logistics career led to students becoming very familiar with logistics or vice versa. In addition, while the demographics of the students who responded to the survey appear to be representative of undergraduate students enrolled in IE programs in the state, the data does come from a sample which potentially could be biased.

In future work, the authors plan to align the student expectations about the 22 factors in this survey with a survey of logistics practitioners about the presence of those factors in the field. This will help companies to better market to the strengths of the logistics field and help faculty educate students about careers in logistics. The authors also plan to expand the study to additional colleges.

\section{BIBLIOGRAPHY:}

1. Wilson, R. (2015), "26 $6^{\text {th }}$ Annual State of Logistics Report”. Chicago: Council of Supply Chain Management Professionals. 
2. The Georgia Center of Innovation for Logistics (2012), "The logistics of education and education of logistics", available at:

www.georgialogistics.com/images/public/reports/Logistics_Workforce_and_Education_Report.pdf (accessed Jul 28 2015).

3. Aquino, D. and Draper, L. (2008), "Supply chain talent: State of the discipline", AMR Research, available at: https://www.gartner.com/doc/1339814/supply-chain-talent-state-discipline (accessed Jul 24 2015).

4. Ruamsook, K. and Craighead, C. (2014), "A supply chain talent perfect storm?", Supply Chain Management Review, Vol. 18 No. 1, pp. 12-17.

5. Knemeyer, A. M. and Murphy, P. R. (2004), "Promoting the value of logistics to future business leaders: An exploratory study using a principles of marketing experience", International Journal of Physical Distribution \& Logistics Management, Vol. 34 No. 10, pp. 775-792.

6. Ozment, J. and Keller, S. B. (2011), "The future of logistics education", Transportation Journal, Vol. 50 No. 1, pp. 65-83.

7. Arnseth, L. (2015), "The logistics workfroce talent crisis", Inside Supply Management, Vol. 28 No. 6, pp. 20-23.

8. Knemeyer, A. M. and Murphy, P. R. (2004), "Promoting the value of logistics to future business leaders: An exploratory study using a principles of marketing experience", International Journal of Physical Distribution \& Logistics Management, Vol. 34 No. 10, pp. 775-792.

9. PwC (2012). "Transportation \& logistics 2030 vol.5: Winning the talent race: http://www.pwc.com/gx/en/transportation-logistics/pdf/pwc-tl-2030-volume-5.pdf (Accessed January 30, 2016.)

10. Twenge, J. M., Campbell, S. M., Hoffman, B. J. and Lance, C. E. (2010), "Generational differences in work values: Leisure and extrinsic values increasing, social and intrinsic values decreasing", Journal of Management, Vol. 36 No. 5, pp. 1117-1142.

11. Hurst, J. L. and Good, L. K. (2009), "Generation Y and career choice: The impact of retail career perceptions, expectations and entitlement perceptions", Career Development International, Vol. 14 No. 6, pp. 570-593.

12. Luscombe, J., Lewis, I. and Biggs, H. C. (2013), "Essential elements for recruitment and retention: Generation Y", Education \& Training, Vol. 55 No. 3, pp. 272-290.

13. Ng, E. S. W., Schweitzer, L. and Lyons, S. T. (2010), "New generation, great expectations: A field study of the millennial generation", Journal of Business and Psychology, Vol. 25 No. 2, pp. 281-292.

14. Extraordinary Women Engineers Coalition. Extraordinary women engineers final report, 2005. Accessed at: http://www.aacei.org/WPC/library/ExtraordinaryWomen-FinalReport.pdf (Accessed January 31, 2016). 